九州大学学術情報リポジトリ

Kyushu University Institutional Repository

The Importance of Kōden in the Establishment of Identity: The Title of the Dainichikyō in the Opening Sequence of the Hizōki

Van Der Veere, Henny

Leiden University : Lecturer

https://doi.org/10.5109/1806141

出版情報: Journal of Asian Humanities at Kyushu University. 2, pp.95-110, 2017-03. Kyushu University, School of Letters, Graduate School of Humanities, Faculty of Humanities バージョン:

権利関係 : 


\title{
The Importance of Kōden in the Establishment of Identity: The Title of the Dainichikyō in the Opening Sequence of the Hizōki
}

\author{
HENNY VAN DER VEERE
}

$\mathbf{S}$ HINGONSHU 真言宗 is a generic term used by a large number of independent organisations based on ritual lineages, each with their specific ideas and their training, and education system. Nowadays, the best known of these organisations is arguably the Kongōbuji-ha 金剛峯寺派 through their headquarters on Mt. Kōya; a century ago that would have been the Tōji-ha 東寺派 located in the old capital, Kyoto. The ritual organisations which employ the name Shingonshū do so because they share a heritage from the past, hold on to training courses for their ritual specialists which have many similarities, and, of course, claim to have their foundation and inspiration in the (alleged) works of Kōbō Daishi Kūkai 弘法大師空海 (774-835). They recognize to a certain extent each other's permits and qualifications, but at the same time show a variety of differences in the performance of ritual and the interpretation of their authoritative works.

In scholarship, especially in contributions by priests belonging to those organisations, a variety of issues, tenets, and ritual practices are taken up from a perspective based on the similarities that keep the concept of Shingonshū together. This is also the general atmosphere in most works by Western academics, many of which concern doctrinal ideas (kyōsō 教相). On the contrary, in the field of ritual studies and studies of practice (jissō 実相 and jissen 実践), these organisations and ritual lineages emphasize what separates them and discern various differences, certainly in respect to the efficacy of altar rituals and in the way their bridge to unification with the absolute world is built. Moreover, research on matters pertaining to "Shingonshü" customarily takes the form of a diachronic approach in which most, if not everything, is traced back to Kükai as originator, or supposes a continuity in the development from the founder Kükai until the present situation.

I see a number of problems in the above-mentioned approach. Firstly, I am not convinced that everything can be traced back to Kükai and his successors or that descriptions that start from the works of Kūkai will yield a historically correct picture of the developments in Japanese history. Further, I think that research into the contemporary situation in Japan, its ritual networks, services, and position in society would become more revealing and fruitful when we consider existing practices without this compulsory connection with the vicissitudes in the long history of ritual practice. We can easily discern organisations in contemporary Japan which, although they screen themselves off from the public eye to a certain extent by professing to have eso- 
teric knowledge which is not available to laics or uninitiated, possess a system of training their priests which is very much their own in the emphases they place on certain aspects traditionally linked with the concept of Shingonshū. During the training and general education of their members in as far as they aspire to become ritual specialists, these organisations, whether they boast a long history or not, are supposed to present a coherent picture of their ideas on ritual in a doctrinal setting, or at least an epistemic for the performance of ritual, its efficacy, and its relationship with the needs of the clients, that is defensible and coherent.

It follows that one path to an understanding of how the ritual specialists organize their lore and cater to their clients, and one way to discover the actual differences between the schools, is to investigate the contents of those education models. Such a line of inquiry would provide insights in the way the various schools define themselves and build their identity, and would show us the systematics and tools of their universe. In other words, instead of approaching the ritual expert from a framework defined from outside the tradition itself, whether that be from Western perspectives on the Japanese religious situation or buddhological approaches informed by nineteenth-century constructions of the East, I prefer to investigate the insider perspective of the priests and the organisation they belong to in present-day Japan. I believe that an analysis of the contents of the transmission system, and especially the initiation lectures called kōden 講伝 will reveal what certain organisations hold most dear, what sets them apart from each other, and, in addition, may bring to light new topics which may have escaped the eye of the observer and remained under the radar otherwise.

In the present article I would like to show how such a study of the workings of the education system may yield some interesting data and focus on the points that are considered unique by a certain organisation through an example taken from the kōden initiation lectures, for my purpose here from the Hizōki kōden 秘 蔵記講伝, the lectures on the Hizoki 秘蔵記, a basic text for many and possibly all ritual lineages. ${ }^{1}$ This one example will support my claim, I hope, that the actual identity and characteristics of contemporary lineages

1 An extensive discussion about the meaning of the title can be found in the commentaries, but "Notes on the Secret Store" may be vague enough to accommodate the majority of interpretations. is (re)defined during these sessions, always under the guise of the perpetuation of tradition. At the same time, my discussion will show some of the ramifications of the explanations which contribute to a more general build-up of lore about the universe of the priest.

The first line of the Hizōki ${ }^{2}$ consists of just the title of the Dainichikyō 大日経 (Mahāvairocana sutra) ${ }^{3}$ and over the centuries much time and effort was spent to interpret this fact. This is the topic I lift from the transmission system to clarify my position. The questions I keep in mind when discussing this example are influenced by an interest in the contemporary situation and in the way the identities that are strengthened during the transmissions and trainings lead to competition and a tendency of monopolizing the truth, while at the same time the overall identity of the Shingonsh $\bar{u}$ construct is sought or accommodated.

Before I go into a detailed discussion of how this topic is treated in the training of ritual specialists and how their "universe" is constructed, I will first describe the general course of the training of the Shingon priest. I then continue with a discussion of the position of koden, the initiation lectures that provide the priests with information on both ritual and doctrine, usually in an integrated form. I hope to show that often and maybe only in these lectures the ideas, the way the organisations define themselves, and matters important for their identity, come to the fore and can become the subject of research when the records of these kōden are used as sources.

After sketching these environments, I discuss the Hizóki kōden, the initiation lectures on one of the basic texts for the ritual framework and doctrinal exegesis of the Shingonshū. I select from these kōden my main example to illustrate the workings of the various education systems, namely the problem of why this authoritative text opens with the title of the Dainichikyō. The exegesis on this riddle has so many ramifications that I will have to limit myself here, but I hope to convince the reader that the discussions on what may seem a minor problem to outsiders to the tradition are instrumental to arrive at some understanding at least about what this kind of education is about. In the process the discussion also demonstrates how such an issue as in my

\footnotetext{
2 Kōbō Daishi zenshū (Osaka: Mikkyō Bunka Kenkyūjo 1965-68) II: 1-73, hereafter KDZ; and Shingonshū zensho (Wakayama: Kōyasan Daigaku Shuppanbu, 2004) IX: 9-39, hereafter SZ. 3 T 18, 848; Ch. Dari jing.
} 
example can be expanded to define a number of basic assumptions that lie at the core of the lineage or organisation that provides this information in their training.

\section{Education and the Transmission of Lore}

All the various organisations that share the Shingonshū heritage and are active in contemporary Japan show similarities in recruitment and training. Summarily, in order to become a qualified priest the aspirant or novice (jusha 受者) first has to seek acceptance by a master (shishō 師匠), take the tonsure (tokudo 得度), and then start his ritual training called shido kegyo 四度加行. In this cumulative practice a number of levels are distinguished related to templates for rituals. The position of the goma 護摩 fire-ritual in the build-up varies according to schools, but in the Shingonshū the Kongōkai 金 剛界 practice, dedicated to the acquirement of the wisdom to discriminate between correct or wrong insights, always precedes the Taizōkai 台蔵界 practice, which entails the actualisation of wisdom in the use of helpful means. This order of practice is a major distinction with Taimitsu 台密 ritual lineages.

The student learns a number of templates through repeated practice in the context of the details and finesses of his ritual lineage ( $r y \bar{u}$ 流), from the "reading" or chanting of sutras and darani 陀羅尼, preparing the altar, cutting the flowers, to mixing the incense and handling a brush to write wooden plaques ( $f u d a$ 札), all skills learnt in order to familiarize himself with the tools of his trade.

Depending on the qualified instructor (ajari 阿 闍利) who is the master of ritual, the content of this training may be basic ritual or may include the specific definitions of the ritual lineage, the hiketsu 秘決, which I translate as 'esoteric definitions', definitions of matters pertaining to the esoteric tradition. The information is conveyed to the novice in the form of denju 伝授, transmission of ritual matters (jissō). There is no doctrinal training involved in this stage.

Although the term shido kegyo suggests that we have to do with four stages, actually there are more and shido kegyo can be treated as a period of seclusion during which the daily round of ritual duties is mastered by imitation, including the veneration of the main deity of a $r y \bar{u}$. The morning and evening rituals are repeatedly performed too. The ritual manuals differ depending on the school, on the legendary background, and so on.
Although information on shido kegyō and translations of the manuals into English are now easily obtainable, I find that hardly any allowance is made in these works for the differences between the schools. ${ }^{4}$ The intricacies of one lineage, such as the Chūin-ryū 中院流, are often treated as if they are the general model for all lineages that bear Shingonshū in their name.

When the practice of shido kegyō is concluded, the novice can apply for the initiation called denbō kanjō 伝法潅頂. This initiation provides the trainee with the basic qualification to work as a ritual specialist and sometimes earns him the title of ajari. He is now permitted to perform various kinds of rituals for the benefit of clients, the laics (zaike 在家). Moreover, he has access to literature and texts which are meant for the eyes of the initiated only, and he is allowed to attend the sessions for further instruction which I will discuss hereafter.

At this point in his career the priest has probably studied Buddhism and the historical background of his lineage in courses at university but may not have been instructed about the specific doctrinal position and ritual points of his own lineage and about his own lineage in contradistinction to other groups, even though he considers himself to be part of a certain lineage. The level of ajari gives him access to the continued teaching of his school or that of other schools. For ritual and practical matters, the priest continues his studies through denju, transmissions, among them the most important being the ichiryū denju 一流伝授. This transmission concerns the complete know-how of one ritual lineage. The student is informed about the contents of the origami 折紙, ${ }^{5}$ folded papers with basic ritual information such as the shingon 真言 (mantra) and in 印 (mudrā hand postures) to be used during specific

\footnotetext{
4 Taisen Miyata, Handbook on the Four Stages of Prayoga; Chūin Branch of Shingon Tradition (Wakayama: Kōyasan Shingonshū Kyōgakubu, 1988) contains a partial translation of the manuals used on Mt. Kōya for foreigners; Richard Payne, The Tantric Ritual of Japan: Feeding the Gods: The Shingon Fire Ritual (New Delhi: International Academy of Indian Culture \& Aditya Prakashan, 1991) focuses on the goma-ritual but provides information on the Mt. Kōya set of manuals as well. Robert Sharf, "Thinking Through Shingon Ritual," Journal of the International Association of Buddhist Studies 26, no. 1 (2003): 51-96 has probably the most extensive discussion on the contents of shido kegyō, heavily influenced by the Daigoji tradition, it would seem, but although referring to the differences (see note 18 in Sharf's article) between the organizations, holds on to a concept of an over-arching Shingonshū.
}

5 These are called kirigami 切紙 in other (later) Buddhist groups. 
rituals, and receives a signed example of these documents. Among these we also find the document which shows his place in the kechimyaku 血脈, the bloodline of his lineage. Besides access to these denju, the priest is also permitted after denbō kanjō to attend the lectures in which instruction in both kyōsō and jissō in integrated form is given, the köden sessions.

In the words of an influential dentō-ajari 伝統阿砂 利 (an ajari who continues the transmissions) from Mt. Kōya, Ōyama Kōjun:

\section{About the understanding of kōden (kōden no koko- roe 講伝の心得): doctrinal instruction (kyōsō) is open to all people, regardless of whether they have received kanjō or not; however, instruction on practical matters (jissō) is limited to those who are initiated, and this is the same for [participation in] kōden. The instructions in the kōden cover both $k y \bar{s} \bar{o}$ and jissō and reveal profound issues; among them the said Hizōki belongs to [the category of] kōden. ${ }^{6}$}

Ōyama then explains that in the case of köden a "permissive initiation" (koka kanjō 許可潅頂) is necessary and that in his lineage (Chūin-ryū) the most abbreviated form is chosen.

There is agreement that in the discussions during the koden the doctrinal and practical ritual lore is combined. Kōden have eminent scholar-priests as instructor and are supposed to imitate the original Shingon myth of Dainichi Nyorai 大日如来 instructing Kongōsatta 金剛薩埵 in the sense that the instructor, the Dai-ajari, is to be considered by the listener as Dainichi Nyorai and the recipient as Kongōsatta. These attitudes and the way the sessions are carried out, the sahō 作法, are based on a text with some short notes attributed to Kükai, ${ }^{7}$ and worked out in the various lineages. Often, the ritual format of such transmissions and the added visualisations are already explained in the first part of the shido kegyō. The provenance of the template in Kükai's works explains the similarity we find between the schools in the format.

Since the instructions of the kōden concern the Taizōkai and the Kongōkai aspects of reality, the ques-

6 Ōyama Kōjun, "Hizōki kōden," vol. 2 of Ōyama Kōjun Sentoku Kakigiki shūsei: Kōdenmon (Osaka: Tōhō Shuppan, 1995): 173-234.

7 Shingon denju sahō in KDZ IV: 417-24. tion may be raised which preliminary visualisation is suited for the recipient Kongōsatta. According to the Chizan-ha 智山派 scholar Nasu Seiryū it is general practice in Tōmitsu 東密 that after the initial body purification (goshinbō 護身法) the Kongōkai visualisation on the stupa and on the syllable BAN is most appropriate. ${ }^{8}$

Ueda Reijō states in the introduction of his kōden on Rishukyō 理趣経 (Naya Sutra, Sutra Giving Guidance towards the Truth) $)^{9}$ like many other records of these transmissions: "Kōden are held on a number of topics such as Rishukyō, Mandarashō 曼茶羅抄, Dainichikyōsho (Oku no sho) 大日経疏 (奥ノ疏) and Hizōki." Here we find a number of categories which touch on the core of the rituals, the exegesis and the tenets of the various lineages that associate with the concept of Shingonshū. This doesn't necessarily mean that all ritual specialists, priests from minor temples and so on, have all attended these sessions. There is no compulsory system for further study after the denbo kanjō, although pressure from the various headquarters or even peer pressure allows for a high turn-out for these instructions.

I believe the actual system of lore and knowledge is not only transmitted in these sessions but also determined by the speakers/transmitters. What is more salient here is my claim that, more than a study of doctrinal works by itself, the discussions in the kōden indicate what is important for the identity of a ritual lineage and how the so-called heritage of Kükai is unpacked at every single confrontation with seemingly divergent views. The approach is by no means based on a binary heterodox versus orthodox or heteropraxis versus orthopraxis discussion, which is also illustrated by the fact that priests from different lineages may attend the lectures of famous ajari-instructors. From experience I know that, having received denbō kanjō as a Buzan-ha 豊山派 priest, an organisation that uses the Daidenboin 大伝法院 lineage, I could attend denju and kōden in a variety of lineages, from the Chūin-ryū lineage to Saidaiji 西大寺 lineages.

\footnotetext{
8 For a more detailed explanation please refer to Nasu's kōdenroku. Nasu Seiryū, "Hizōki kōden," vol. 7 of Nasu Seiryū chosakushū (Kyoto: Hōzōkan, 1997), 3, for the mental preparation of the student.

9 Ueda Reijō, Rishukyō kōroku (Kyoto: Dōmeisha, 2002), 6.
} 


\section{Hizōki Kōden}

My intention here is to illustrate how fruitful a study of kōden and exegetical literature can be for a fuller understanding of the way the different lineages view themselves and to emphasize that there is no one Shingonshü but a variety of lineages who together adhere to this concept. Because the lineages hold on to their own interpretations of basic texts and tenets, a mere translation of any sentence tells us preciously little about the meanings that are contained in the systems of the lineages nor does it inform us about the salient points within the overall architecture.

When I take up my example from the Hizoki I am fully aware of the discussions about the date of composition and the unresolved problems in manuscript study, the actual number of its volumes (one or two) or chapters. The composition of the original text is dated by scholars such as Mukai Ryūken ${ }^{10}$ to after the introduction of the Shōmuge-kyō 攝無碍経 ${ }^{11}$ in 986 while the conclusions drawn by Ōzawa Shōkan, ${ }^{12}$ a date before 878 , are serious enough to warrant further research..$^{13}$ It is hard to pin the composition to an exact date or year but it seems most likely that both the Hizōki and the twenty-five-article testament (see below) came to the fore in the time of Kangen 観賢 (853-925) who was instrumental in the awarding of Kükai's posthumous name of Kōbō Daishi.

The Shingon schools consider the Hizōki to be a collection of notes made by Kükai during the instruction he received in China under Huiguo 惠果 (Jp. Keika, 746-805). The Tendai 天台 (Miidera 三井寺) view is mostly that these were the notes Huiguo took when

\footnotetext{
10 Mukai Ryūken "Fukūyaku Shōmugekyō to Hizōki to no kankei ni tsuite," Buzan kyōgaku taikai kiyō 9 (1981): 13-24; and "Hizōki seiritsu kō," Mikkyōgaku kenkyū 15 (1983): 53-67.

$11 \mathrm{~T} 20,1067$. I use the conventional abbreviated name because the full title is exceptionally long. See Mikkyō Jiten Hensankai, ed., Mikkyō daijiten (Kyoto: Hōzōkan, 1991), 1205.

12 Ōzawa Shōkan, "Hizōki no ikkōsatsu," Taishō Daigaku Daigakuin kenkyū ronshū 1 (1977): 95-108 and "Hizōki no senjutsu nendai n tsuite," Mikkyogaku kenkyū 24 (1992): 47-61 draw attention to the fact that Hizōki is mentioned five times in Rokutsū jōki 六通貞記 (Six Messages Recorded by the Abbot of the Jōkanji [Shinga]), an important text for the Nishinoin-ryū 西院流. This text is dated 878 , so our text must have been composed earlier. I am not convinced of this date and its ascription to Shinga 真雅 (801-79) for several reasons. For one, the text cites the Goyuigō 御遺告 (Final Instructions), which I think dates from the beginning of the tenth century. More research is needed in this case as well.

13 Ueda Reijō, Hizōki kōden (Kyoto: Dōmeisha, 2002), 12.
}

he studied under Amoghavajra (Ch. Bukong 不空, Jp. Fukū, 705-74). There is no autograph by Kükai nor is there an extant definitive version. In a manuscript from 1313 it is recorded that Gahō 我法 (Jishō shōnin 自性 上人, ?-1317) tells his students that in the days of Raijo 頼助 (1246-97) an effort was made to reconstitute the original text by comparing all manuscripts but this ended in failure. ${ }^{14}$

Putting the problems with the manuscripts aside for now, I think it is better to speak of a meta-text, an idea about what the Hizōki is and means, and the divergences we can discern among the lineages do not harm the authority of the text as an idea. The text in Shingonshu zensho is a compromise text which can be divided, depending on the school, in a number of chapters, from ninety to a hundred depending on the commentator.

The Hizōki kōden can be traced from the thirteenth century on, although not always in complete form. The oldest extant record of a Hizōki kōden, the Hizōshō 秘 蔵抄 (Commentary on the Hizō[ki]), is dated 1222 and was written by the Daigoji priest Shinken 深賢 $(?-1261)$ who attended the explanations by Jōken 成賢 (11621231) in sessions that took place on Mt. Kōya. ${ }^{15}$ A comparison of recent records (kōdenroku 広伝録) shows that the various lineages, although recognizing the value of many older records, place emphasis on works that contain the essentials for their tradition. For Daigoji Sanbōin 醍醐寺三宝院 lineages scholar-priests such as Gōhō 果宝 (1306-62) are authorities, in the Chūin-ryū the records of the instructions by Dōhan 道範 (1178-1252) and Yūkai 宥快 (1345-1416) are paramount.

The template of the records and commentaries often resembles a syllabus. They contain an outline followed by the order of the discussions and of the points that the ajari introduces. They may be in the form of summary notations of the main subjects under discussion, or again more elaborate texts with discussions on all points of the instruction. At times these notes were recorded by the instructor himself, but we find many

\footnotetext{
14 See Nakagawa Zenkyō, "Hizōki ni tsuite no josetsu," Mikkyōgaku kenkyū 1 (March 1969): 42

15 The Hizōshō (1 kan) is often referred to as the (Zōchū) Yakinshō (蔵中)冶金抄. It mentions as instructor Henchiin Jōken and as recorder Shinken 深賢 (?-1261), who was the founder of the Daigo Jizōin 醍醐地蔵院. The transmission took place in Jōō 貞 応 1 (1222) in Ōjōin Rengenotani 往生院蓮花谷 of Mt. Kōya. The text is included in vol. 15 of Zoku Shingonshū zensho (Wakayama: Kōyasan Daigaku Shuppanbu, 2008), hereafter ZSZ.
} 
instances of notes taken by a listener and approved afterwards by the ajari. These collections are generically called kōdenroku.

There are a number of quite recent kodenroku of the Hizōki available, ${ }^{16}$ but for my exposition here I limit myself to the kōdenroku of Oda Jishū and Ōyama Kojun, Nasu Seiryū, and Ueda Reijō, the first two belonging to the Chüin-ryū, the third to the Chizan-ha, and the last to the Daigoji Sanbōin Dosen-ryū. These records are structured along the same patterns we can discover in older commentaries; they can be viewed as the continuation of tradition. Many of these older records show the number of days the full instruction took, and an order similar to contemporary sessions of the problems they discuss, starting with authorship, the authoritative commentaries for the lineage, and so on.

The usual kōden starts off, after the ajari relates how he was himself instructed, with a discussion of the manuscripts, the main commentators of the lineage and references to writers from other lineages, and so on. For my purpose, an illustration of the wide-ranging meanings exegetes found in just the first sentence of the Hizōki, I mention here the important role of the commentaries by Dōhan and Yükai for the Chūin-ryū and Gōhō and Ryūyu 隆瑜 (1773-1850) for Daigoji and Chizan-ha.

\section{The First Line of the Hizōki}

The oldest manuscripts of the Hizōki have no chapter titles. Ueda Reijo ${ }^{17}$ uses the titles from the manuscript owned by commentator Gōhō for the discussion and in transmission. Ōyama prefers writers from the Mt. Kōya lines, starting with the oldest in existence, Shinken's, and subsequent commentaries. The editor of the text in Shingonshu zensho says: "the division in chapters of this present $[\mathrm{Hiz} \bar{o}] \mathrm{ki}$ is made on the basis of the Hizōki shūyōki 拾要記 [1842 by Ryūyu] and the Hizōshō [7 kan; 1283 , author unknown]."

16 Nakagawa, "Hizōki ni tsuite no josetsu," 42 however, states that there are no recent ones for the Hizōki, probably because he does not allow for the fact that there may be several decennia in between kōden, as was the case before the twenty-first-century kōden of Ueda Reijō.

17 Ueda Reijō, Hizōki kōden, 2002, prepared for the kōden at Shuchiin Daigaku from 2002 until 2004

18 SZ IX: 9. Not to be confused with Shinken's work with the same title from 1222.
There are Hizōki manuscripts with a title on the cover, a title on the first page, or without any title, but all manuscripts, as far as I know, have as the first entry the title of the Dainichikyō. Some lineages and commentators count this as a chapter in itself, others as a mere opening. The first thing I can say is that a mere translation of this title will do no justice to what the traditions have to say about this sentence in this specific context. Every sentence or character is supposed to be there for a reason.

In the commentarial tradition and the kodenroku, the problem of the first sentence is referred to as "Title of the Dainichikyo." ${ }^{\prime 19}$ It is counted as a separate chapter by Ueda Reijō but not by Oda Jishu and Ōyama Kōjun, an initial difference between Daigoiji and Mt. Kōya lineages, although admittedly not a major one. Such qualifications of divisions within the text lead to divergences in the number of chapters the commentators give, from eighty-seven to a hundred. ${ }^{20}$

This opening sentence runs:

\section{摩訶毘盧遮那尾三菩提美紀梨儞地瑟他蘇多覧}

Makabirushana. bisanbōji. bikirini\{ta\}. chishuta. sotaran.

The first line thus contains no more than the Sanskrit title of the Dainichikyō written in Chinese characters used phonetically.

In the Taishō canon ${ }^{21}$ the title of the translation from the Sanskrit by Subhakarasimha (Ch. Shanwuwei 善無 畏, Jp. Zenmui; 637-735) and Yi Xing 一行 (Jp. Ichigyō, 683-727) is Daibirushana jōbutsu jinpen kaji kyō 大毘 盧遮那成仏神变加持経. Ueda Reijō and Oda Jishu follow the old commentaries who refer for the reconstruction of the Sanskrit title to Kükai's commentaries ${ }^{22}$

19 Oda Jishu, "Hizōki kōden kiyō," in vol. 2 of Oda Jishu kōdenroku (Osaka: Tōhō Shuppan, 1990). Gōhō's chapter in his Hizōki shishō, is titled "Makabirusha no koto." Gōhō, Hizōki shishō, in Shūtenbu Shingonshū jissō shōsho, vol. 85 of Nihon daizōkyō (hereafter Nichizō) (Tokyo: Kōdansha, 1976), 109. Likewise Shinnichi (?-1309), author of Hizōki kanmon 秘蔵記勘文, has a chapter, titled "Dainichikyō no koto." ZSZ XVI.

20 Interestingly, Gōhō remarks that he opts for a hundred chapters because of the "fullness of the number." Hizōki shishō, in Nichizō 115 .

21 See also Paul Demiéville, Hubert Durt, and Anna Seidel, eds., Répertoire du canon bouddhique Sino-Japonais: Edition de Taishō. Hōbōgirin, appendix volume (Paris: L'Académie des inscriptions et belles-lettres, Institut de France, 1978), 78.

22 Kūkai wrote seven introductions to this text (kaidai 解題). See, for example KDZ IV: 3 
where the title appears in shittan script: Mahā vairocanābhisaṃbodhi vikrnitādhiști sūtram indrarāja. ${ }^{23}$

It is tempting to enter the discussion here about whether the text should be classified as a sutra, the Japanese view, or as a tantra, the Indian and Tibetan classification. I would stray too far from my purpose here, the working of the koden, when I would introduce into the discussion commentaries on this text that were not used and/or known by the exegetes of Japan. I think that this is a defensible choice since references to Indian commentaries such as Buddhaguhya's ${ }^{24}(f l$. eighth century) are not found in the commentaries I use.

Kükai wrote a number of treatises in which he presents his interpretations of the ideas and ritual directions recorded in the Dainichikyō. For him, this text was pivotal to the defence of his ideas on, for example, the stages of the mind's development and the nature of insight as nyojitsu chijishin 如実知自心 (“jitsu no gotoku jishin o shire") as well as the main practice of the five-syllable shingon. He considered the way this text treats the nature of the absolute Buddha (hosshin 法身) and its preaching (A-ji honpusho 阿字本不生) as the culmination of doctrinal thinking and used it to confirm his paramount position relative to other (non-tantric) schools, as here was the profoundest insight into the Dharma. Kükai's substitution of causation from the six great elements (rokudai engi 六大縁起) for causation from honpushō (honpushō engi 本不生縁起) is discussed in later parts of the kōden but not here in relation to the title.

\section{A. THE EXPLANATION OF PHRASES (KUGI 句義)}

In the exegetical literature of the Shingon schools the commentators address as many issues as they can find, it would seem, but the determination of the category to which the issue under discussion belongs is considered a sine qua non in many cases. All language constructs can be explained on various levels, from the meanings in the everyday world to the most profound embedded meanings. A certain shingon may be explained from the meanings of the words it contains or from the mean-

\footnotetext{
23 Also known as Mahāvairocanābhisaṃbodhi vikurvitādhișthhāna sūtram Indrarāja.

24 For one view on those continental traditions, see Stephan Hodge, trans., The Mahā-vairocana-abhisambodhi tantra: With Buddhaguhya's Commentary (London: RoutledgeCurzon, 2003). This work does not account for the specific Japanese interpretations, notably the development of bodaishin through three stages, and is therefore of not much use for the present study.
}

ings attributed to the individual syllables. The first discussion is therefore often about the meanings of the phrases ( $k u$ 句) of a sentence, of a shingon, or of a statement. The kugi thus opens many an explanation and I follow the convention here.

In the Dainichikyō kaidai (Hokkaijōshin)25 大日経 解題 (法界浄心) (Introduction to the Mahāvairocana Sutra: The Pure Mind of the Dharma-World), Kūkai gives as the full title of the Dainichikyō: Daibirushana jōbutsu jinpen kaji kyō indaraō. In the ensuing discussion of the parts of this title he distinguishes between original Sanskrit words (birushana, butsu, ind[a]ra) and Chinese words (dai, jō, jinpen, kaji, kyō and ō). A full translation of the Sanskrit words into Chinese characters and Japanese pronunciation would yield Dainichi 大日 joan henmyō 除暗遍明 jōshō gakusha 成正 覚者 jinpen kaji 神変加持 $k y \bar{o}$ 経 Taishaku 帝釈-o 王. 'Mahä', which is written in shittan-script, means 'great' (dai); 'Birushana (Vairocana)' means 'the sun, the darkness removing, expanding light' (Birushana); [a] bhisambodhi' means 'having reached complete insight' (jōbutsu); 'vikrnnita' means 'mystic changes' (jinpen); '[a]dhiști' means 'unification (kaji)'; 'sotaran' means 'sutra' ( $k y \bar{o}$ 経); 'Indrārajā' means 'Taishaku-ō'.

It did not escape the attention of commentators ${ }^{26}$ that the Indian deity Indra is lacking in the versions of the text in current use as well as in the title here. Actually, the Dainichikyōsho 大日経疏, the commentary on the Mahāvairocana Sutra compiled between 725 and 727 , the basic commentary in the Shingon schools, mentions this addition as part of the Sanskrit version. ${ }^{27}$ There is also a difference between 'vikrnita' and the more common 'vikrvita/vikurvita,' but I have found no comment on this as yet.

\section{B. ESOTERIC READINGS}

Shingon exegesis frequently uses a further method, specific to their transmissions, as a tool to discover and explain esoteric meanings and content of texts. This approach is found appended to doctrinal explanations, or at times as the main concern of the commentator. In this case as well it is possible to read

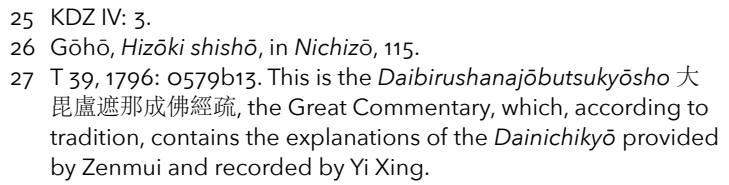


esoteric lore in the title itself, applying the concept that the ideal world of realization is integrated in all thought, matter, and language of the world of the senses. Esoteric Buddhist concepts can be discovered as submerged meanings, or can be projected and distributed over any appearance, becoming their superior attribute.

I already introduced Shinken as the author of the earliest extant kōden record, the Hizōshō of 1222. In this work, he interpreted the title as a concise statement about real existence in four aspects: its essence, nature, function and appearance. This real, or absolute, existence is comprehensively described by the three bodies and the five wisdoms of Dainichi Nyorai. The three bodies are Makabirushana $=$ hosshin $;$ jōbutsu 成仏 = hōjin 報身; jinpen kaji 神变加持 $=\bar{o} j i n$ 応身. In a similar way the five kinds of wisdom are distributed over the parts of the title: the hosshin comprises the wisdom of daienkyō-chi 大円鏡智, byōdōshō-chi 平等性智, and hokkaitaishō-chi 法界体性智; jōbutsu corresponds to myōkansat-chi 妙観察智; while jinpen kaji stands for jōsosa-chi 成所作智. This explanation may have been transmitted as part of the kuketsu of certain lineages since neither Ueda Reijō's kōden nor the commentators from this lineage refer to it, as far as I have been able to discover.

The unknown author of the Hizōsho from 1283 explains, similar to Kükai's explanations in the aforementioned Kaidai, that 'Maka' stands for 'Dai', which refers to the rokudai hosshin, Birushana for the sun, and bisanboji for jobutsu. ${ }^{28}$ In the form of a dialogue, he compares the specific shingon meanings with Taimitsu interpretations, which are different.

The focus of his discussion is on the difference in meaning of the term jöbutsu since the Taimitsu scholar Annen 安然 (?841-?915) uses the same phrase, jōbutsu. To elucidate, the unknown author pulls the card of exoteric-esoteric division and explains that the meanings are not the same as there is a difference between kengyō 顕教 and mikkyō 密教, between a shallow and profound level of analysis. He postulates that the jōbutsu in the title of the sutra refers to hōni no jōbutsu 法爾成仏, the Buddha-hood as the inher- ent absolute in itself and by itself, and not hōni zuien jōbutsu 法爾従縁成仏, the attained Buddha-hood reached through conditional progress starting out from the inherent absolute. The Rishushaku-kyō 理趣 釈経 ${ }^{29}$ is quoted to show that the complex under discussion here is the wondrous body of all the various Nyorai in their unshared reality. From this complex mentioned in the title, represented by the syllable UN (Sk. hūm), everything, both man and the five great elements come forth. Basically, he continues, the eight schools (kengyō) differentiate between man and dharma, while a basic Shingon tenet is that Man is Dharma (jin soku hō 人即法) and Dharma is Man (hō soku jin 法即人). The absolute inherent in all is Dainichi in essence, substance, action, etc.; in other words, hōni jōbutsu. Thus, the commentator writes, "jōsanboji" in the title refers to the Dharma, and Annen's jōbutsu is the term for Man.

To follow our unknown writer somewhat further to get an idea of the exegetical atmosphere, the next explanation in this commentary concerns the term "Vikirini" which is explained as "mysterious transformations" (shinpen 神变). These function in four ways: when flowing downwards, retrogressively, it indicates a causal history of transformation leading back to the source, original enlightenment (hongaku no engi 本覚 縁起); upwards, progressively, it leads to the pinnacle of initial enlightenment (shigaku no jōten 始覚上転); when the transformations work sometimes up and then down, we notice the working of the five wisdoms and the four bodies; when there is no transformation upwards nor downwards, the term refers to all sentient and non-sentient beings and all constructed and non-constructed (sanskrta and asanskrta) dharmas, which are essentially represented by the syllable A of non-production.

When the koden thus discuss the opening line, they introduce the topics of the commentators not only as historical precedents but also in order to distinguish the general Shingon thought from other groups and in addition they add to the store of the audience's knowledge while wielding the analytical tools that are characteristic for their organization.

28 Hizōshō, SZ IX: 41. This commentary is also known as Hizōki shimonsho 秘蔵記私聞書 (Personal Notes Regarding [Aural Instruction into] the Hizōki). It contains the record of a transmission that took place in Kōan 弘安 6 (1283) in Kamakura Sazame no tani 鎌倉佐々目谷.

29 Sutra Explaining the Guidance towards the Truth, a work attributed to Amoghavajra. T 19, 1003. 


\section{Why Does the Text Open with the Title (Only)?}

The koden then explain that commentators propose various reasons, historical and doctrinal, as to why the Hizōki opens with the title of Dainichikyō. Since the writer is supposed to be Kükai, historical reasons are sought in Kūkai's life and the known biographies. Raihō 頼宝 (1279-1330), for example, assumes that Kūkai placed the title of the sutra at the beginning, and thus accorded it prime place, as a result of the major role this sutra played in the course of his public career and his private life. ${ }^{30}$ There is general agreement that Kükai's initial motive to go to China was to learn the full meaning of this sutra after he discovered it, as the story goes in many biographies, under the pagoda of Kumedera 久米寺, acting upon a revelation in a dream or in meditation. I turn, in the company of the exegetes, to one of the basic texts of the Shingon traditions, the Goyuigo 御遺告 (Final Instructions), to situate this event and highlight the importance of the Dainichikyō for Kükai's career in the framework of accepted lore of the Shingon school. During the köden this becomes an opportunity to ascertain the importance of this text and to instruct the listeners in its contents.

\section{A. THE "FINAL INSTRUCTIONS"}

It may come as no surprise that Kūkai's final instructions to his disciples before his death carry great weight for all those who consider themselves keepers of his heritage. These instructions, of which there are several redactions and versions under the name (go)yuigo or (go)yuikai 御遺戒. The version of Goyuigō that would become one of the most influential texts for the Shingon traditions, the so-called "Final Instructions in Twenty-five Chapters” (Goyuigō nijūgokajō 御遺告 二十五箇条), ${ }^{31}$ in all probability dates from the tenth century. ${ }^{32}$ In the same way as the Hizóki is the back-

\footnotetext{
30 Hizōki kikigaki from 1309, ZSZ XV: 62a. The lecturer was Jishō Shōnin Gahō.

31 KDZ II, kan 7: 781-808.

32 See, for example, Takagi Shingen, Kūkai: Shōgai to sono shūhen (Tokyo: Yoshikawa Kōbunkan, 1997) for biographical details and Ueyama Shunpei, Kūkai (Tokyo: Asahi Shuppansha, 1992 [2002(3)]), 133-55 for the impossibility of Kükai as the author of the various testaments. For the tenth-century theory both writers propose, I refer also to my forthcoming study on the place of the Goyuigo in the construction of the Shingon tradition as derived from Kūkai.
}

bone for the ritual practice of most Hirosawa-ryū 広 沢流 schools, this “Testament," as it is called by some translators, ${ }^{33}$ contains basic lore for the Ono-ryū 小野 流 schools and contains indispensable information for some of their major rituals.

A few words may be necessary on the position of both the Hizōki and the Goyuigo as well as their use in esoteric Buddhism. The division in lineages that can be traced back to Hirosawa 広沢 pond or the Mandaraji 曼茶羅寺 in Ono 小野 continues to the present day due to basic differing interpretations in ritual and exegesis thereof, although many of the contemporary lineages are the result of cross-fertilisation and ever-newer interpretations by leading ritualists. There are also lineages belonging to none of the above two, such as Kojima-ryū 小島流. Although ritual transmissions make their own selection to create a curriculum for the study of both theory and practice, they are not exclusive in the sense that initiated priests from other lineages are not admitted to denju and köden sessions as described above. Depending on circumstances and teachers, such lineages are changing continuously by combining the contents of various transmissions while preserving their distinguishing elements brought to the fore by the founder; at least that is the pretension.

In the present case as well, all schools make use of both texts and freely cite from them. The precise interpretations of the contents of these texts and their esoteric definitions, such as the hiketsu, are transmitted in ritual settings, kōden for the Hizōki, and denju, often part of the ichiryū denju, for the Goyuigō.

The first chapter of the Goyuigo has effectively become the approved biography of Kūkai, although historians have highlighted a number of problems and fabrications. This biographical chapter relates that at one time Kükai implored the buddhas to reveal to him the ultimate truth of Buddhism, which he had not been able to discover even after wide-ranging studies. The young Kükai then received a revelation in which a person appeared who informed him about the existence of the Dainichikyo which could be found in Kumedera: "That is the text you need." ${ }^{34}$ The Goyuigo describes how Kükai got hold of the Dainichikyō and ascribes Kūkai's problems to understand the text fully to a lack

\footnotetext{
33 "Abschiedsworte" in Herman Bohner, "Kobo Daishi," Monumenta Nipponica 6, no. 1 (1943): 281. $34 \mathrm{KDZ}$ II, kan 7: 783
} 
of esoteric specialists in Japan able to explain the Sanskrit parts that appear in this sutra; at least, that is one way to read the text.

The exegetes Dōhan and Gōhō quote the relevant passage from the Goyuigō. ${ }^{35}$ Dōhan states: "this sutra was the reason why Kükai wanted to study in the Qinglongsi (Jp. Seiryūji 青龍寺) and therefore he placed it ['s title] at the beginning of this work." Gōhō puts this in dialogue form. "Question: Why is the orally transmitted definition (kuketsu 口訣) of the Dainichikyo placed first? The basic motive for Kōso Daishi [Kūkai] to go to China in search of the Dharma stems from the mystical revelation (kantoku 感得) he received about this sutra." ${ }^{36}$ Gōhō writes that according to such works as the Goyuigo and the Kumedera ryūki 久米寺流記 (Historical Account of the Kumedera) the first thing Kūkai asked after he met his teacher Huiguo in China were his definitions (ketsu 訣) on points that were unclear to him.

\section{B. KUMEDERA RYŪKI}

Kumedera ry $\bar{u} \mathrm{ki}^{37}$ is the legendary history of Kumedera, the temple where Kūkai read the Dainichikyo for the first time. The question how the sutra came to be there becomes a matter for investigation and consequently the information in the historical account of this temple as well. The commentators are familiar with this text and drag it into the explanations, especially because this record contains a tale involving the translator of the sutra, Zenmui, and the vicissitudes of the sutra. Zenmui, a prince, had come from India to China in 716 and became highly favoured by the Emperor who appreciated him for his knowledge of Buddhist matters. The tale relates how Zenmui then travelled from China to Japan; he is depicted as a travelling man in the time he worked in India as well, but once arrived in Japan, he found nobody spiritually developed enough to understand his teachings, whereupon he hid the scrolls of the Dainichikyo under the support pillar of the East stupa of Kumedera. Whether the text was translated already from Sanskrit into Chinese ${ }^{38}$ is discussed below.

At this point, the commentators run into the problem of reconciling the mythology that had developed around the famous masters with the historical facts as they knew them. Of course, we can leave the fiction of Zenmui actually coming to Japan for what it is, a tale, but in view of the importance of correct transmission and out of respect of the past, this was impossible for the commentators, who looked for a perfect reconstruction. A description of the way they handled this problem also provides insights in the logic that structured the debate, although this formed no part of the transmission.

Gōhō lifts the story from the Kumedera ryūki and relates that Zenmui brought the text with him to the land of "Ubō-matai" 烏卯馬台. ${ }^{39}$ "Ubō" is one of the old names for Japan, ${ }^{40}$ "Matai" can be short for "Yamatai." Gōhō explains that when Zenmui looked for a place to enshrine his scrolls, he came to Takechi 高 市 in the province of Yamato, written 大日本国. Some three years later, he built a hall near the East stupa here, setting up a "precious shrine" using three grains of busshari 仏舎利, relics of the Buddha-body. The set of seven scrolls of the Dainichikyo is used as support for the central pillar. Gōhō's text then explains the correspondences and metaphors it discovers: the stupa (datō 駄塔) is the remnant/residue of the body that emanated in our world as Shaka, while the lord of the sutra, Birushana, is the complete complex of all emanations, shana. "However, the great potential of this small country was not ripe yet [for esoteric Buddhism]." ${ }^{41}$ Zenmui left the text behind and returned to China. Later Kūkai obtained this sutra.

Gōhō digs up an intricate web of allusions and metaphors in this tale, constructed, we may assume, in the course of the historical development of the transmissions. In fact, his method is a model of esoteric exegesis, which makes it worthwhile to dwell on this great example of esoteric reasoning somewhat longer.

The question Gōhō and his fellow-commentators

35 Hizōkishō, ZSZ XV: 37a. This commentary contains the explanations by Jōhen 静遍 (1165-1223) which were recorded by Dōhan. Gōhō's remark is found in his Hizōki shishō, in Nichizō, 115. 36 Hizōki shishō, in Nichizō, 115.

37 In Shakkebu, vol. 27 of Zoku gunsho ruiju and Jishibu 3, vol. 85 of Dainihon bukkyō zensho (Tokyo: Bussho Kankōkai, 1912-22). The manuscripts go back to at least Genkō 3 (1333). 
faced concerns the reason why Zenmui left the text at Kumedera and why this was a suitable place. His explanatory logic works on the basis of standard esoteric metaphors and symbols within an extended network of parallel meanings, paronomasia, similarities and set associations discovered in both pronunciation and meanings of certain characters, especially around the character for Sun 日 as in Sun-Buddha and as in Dainichi.

The first part of the explanation introduces the location as a reijo 霊場, a place of extraordinary spiritual value. The said location is thus suited to enshrine the major text, in this case as a concrete fundament of the supporting central pillar of the stupa. What is more, the place itself must have been considered receptive for the teachings of Zenmui's esoterism by prior association found in its name, which already shows that this province (kuni 国) is a region where the jishō hosshin hōni 自性法身法爾 (the unconstructed dharma state in itself of the dharma body in its own nature), (a qualification of the nature of) the lord of the sutra (the great sun $=$ Dainichi), was already present. In other words, Gōhō wants to say that the ideal conditions were there because the characteristics of the place were those of reality in its basic subsumed form. That is precisely the reason why the province is called 大日本国. This concept (of spiritual presence) corresponds to the kami Ōhirume no mikoto 大日霊貴尊, he adds.

Gōhō then argues: ${ }^{42}$

The province also goes by the name of 烏卯馬台. 鳥 is used in the text to refer to the sun-disc, ${ }^{43}$ 卯 stands for the moon but [the combination Ubō] also means the [land in the] east because that is where the sun rises. The name Matai 馬台 (horsestand) refers to Nittenshi 日天子, who rode a horse-cart with eight horses over the course of the sun. Now, the virtuous qualities of the [subsumed] truth (ritoku 理德) which are "framed" by the Taizō mandara, are under the control of the sundisc, while the qualities of wisdom as presented in the Kongōkai have the form of [= appear on] the moon-disc. Western India is called Gesshi 月 氏, the eastern region is called Japan. The Shingon (sic) patriarch Ryūju (Nāgārjuna) belonged to the

43 The first character of Ubō may refer to the three-legged crow in the sun and the second to the hare in the moon, meanings that are important for Gōhō's handling of a supposed sub-text.
}

Gesshi (Yuezhi) tribe and he was the one who opened the Iron stupa in South India to spread the teachings contained in the Kongōchōgyō 金剛頂 経 [cycle]. Kōso Daishi was born in Japan and had a revelation about the Dainichikyō [stored] in the East-Stupa of Kumedera.

Gōhō basically says that the Iron stupa in the west reveals the Kongōchōgyō cycle while the Kumedera East stupa produces the Dainichikyō. In this way, although a bit between the lines, the writer compares Kükai with Ryūju, eventually both patriarchs, and connects the Japanese patriarch with the mythical opening of the Iron stupa in India, which is a metaphorical image for reaching insight in itself anyway. The patriarchs are linked in transmission and in their relationship to the sutras. Although I cannot be sure, it may be that Gōhō also intends to do away with the historical and causal categories in these associations and treats the matter under discussion with the tools of the Shingon approach from the domain of realization, in a sense breaking down time and space.

I suppose Gōhō was aware of Kūkai's idea in the Fuhōden 付法伝 ${ }^{44}$ that both the Taizō- (Dainichikyō) and Kongōchōgyō practices were transmitted by Nāgārjuna from the Iron stupa to mankind, and he may also have been aware of the different, and historically later, division of the bloodlines (kechimyaku) from these sources made in Taimitsu since Ennin 円仁 (794-864) and Enchin 円珍 (814-91). I will leave this problem to another opportunity.

The author then unfolds the esoteric geography of the world. He continues with an explanation of the dual system of sutras, directions, and locations arguing that:

Iron in the system of correspondences between the five elements ( $g y \bar{o} / j i n g$ 行) governs the western direction and refers to the mandara ${ }^{45}$ hung on the western wall of a Buddhist hall, i.e. the Kongōkai mandara. [As a projection] the height of this stupa

44 The full title of this work is Himitsu mandarakyō fuhōden 秘密曼茶 羅教附法伝. KDZI, kan 1: 1-50.

45 I prefer to use the Japanese word mandara instead of mandala to avoid misinterpretation; mandara in Shingon exegesis does not only mean "domain" but has the added meaning of the ways in which Dainichi Nyorai pervasively displays the universe as an act of compassion. In this fragment, the pictoral mandala is meant as well. 
is sixteen $j \bar{o}$ 丈, ${ }^{46}$ reflecting the sixteen bodhisattvas of the Kongōkai. This [Kume-dera] pagoda governs the eastern direction and stands for the mandara [hung in] the east. Its height is eight $j \bar{o}$ expressing the eight lotus petals of the [central Hall of the] Taizo mandara. He who abides in India [Ryūju] in the west spreads [the transmission of] the Kongōkai, the man in the east [Kūkai] the Taizōkai. That is the true working of the unconditioned dharma domain (hōni dōri 法爾道理). This all is not the result of conditional [karmic] activity. Of the eight patriarchs, Ryüju is [still] placed to the west of the altar, Kōbō Daishi to the east of the altar. Isn't this the reason here [why the title appears as the opening of the texts] ${ }^{47}$

\section{C. HISTORICAL PERSPECTIVES}

Following these discussions, commentators such as Gōhō scrutinized the historical information. He explains that according to "a certain text" Zenmui came to China in Kaiyuan 開元 4 (716) and the following year he translated the Gumonji-ho 求聞持法 (Ritual Practice for Perfect Memorization). Thereafter, he set about translating the Sanskrit text of the Dainichikyō, which was finished in Kaiyuan 12 (724). He came to Japan in Kaiyuan 5 (717) and left this translation in Kumedera. Gōhō wondered if there might be a mistake in the sources, because this chronology would imply that the translation was not finished in 717 .

When Kūkai eventually found his master in China, he first inquired about points obscure to him in the Dainichikyō. Gōhō, and others with him, then wondered: Why is it then that only the title is given and not the orally transmitted definitions (kuketsu)? The answer is that the kuketsu concern the complete sutra in seven scrolls and are rather extensive (kōhaku 広博 or broad learning) and, since a commentary by Zenmui exists, the title is placed first as a reference that the kuketsu must be consulted.

\section{D. WAS THE SUTRA IN SANSKRIT OR CHINESE?}

Another point that worried the commentators was

\footnotetext{
46 One jō (ten shaku 尺) may mean a length of around 3 meters, which would yield a height of forty-eight meters or may mean the height of a grown man, often said to be 1.7 meter but people were somewhat smaller in the fourteenth century. The general idea is sixteen or eight times the length of a grown man. 47 Hizōki shishō, in Nichizō, 116.
}

that the presumed author of the Hizōki had a choice between the Sanskrit and the Chinese titles to open his text, so why is the title in Sanskrit, although written in Chinese characters that were used phonetically? Some are of the opinion that the text left in Japan by Zenmui was in Sanskrit and, therefore, an Indian manuscript. To corroborate this solution they refer to volume six of the Fusō ryakki 扶桑略記 (Brief History of Japan, late Heian period) which reads: "according to a certain record the Tripitaka master (sanzō 三蔵) Zenmui of the great Tang came to Japan in Yōrō 1 (717)." ${ }^{38}$ The commentators omit the following remark that no textual corroboration could be found by the compilers of the Fusō ryakki. This year corresponds to Kaiyuan 5 (717) and, as mentioned above, the translation was finished (only) in Kaiyuan 12 (724). Thus, holding on to the idea that Zenmui came to Japan in 717 , some exegetes conclude that he must have left the Sanskrit manuscripts behind. Kūkai would have asked his teacher in China first about this Sanskrit version and that is why the Hizōki, the record of his discussions with his teachers, commences with its title.

Gōhō then offers his personal opinion. He asserts, numbering his arguments as follows, that the sutra brought to Japan and found by Kükai must have been the Chinese translation because: ${ }^{49}$

"Zenmui brought the Dainichikyō to benefit the sentient beings in the eastern realm. This region [Japan] has no practice and use of Sanskrit. How could this be a Sanskrit book?"

"The Goyuigō says: a certain person announced [in a dream/meditation to Kükai]: [in Kumedera there] is a sutra by the name of the Daibirushanakyō. This revelation in Kükai's dream already used the title of the Chinese text. How could that be a book in Sanskrit?"

"The same text tells us that Kükai "loosened the cords and browsed the text, but the meanings of many places remained abstruse for him.” The phrases (bunsei 文勢) that were legible or intelligible must have been in Chinese."

Further, the Dainichikyō is not listed in Kūkai's Go-

\footnotetext{
48 Entry under Empress Genshō 元正 (r. 715-24) added to the remark that Dōji hōshi 道慈法師 returned from the Tang. Dōji (?-744) learned the Gumonjihō from Zenmui in Chang'an and after his return came to live in the Daianji 大安寺, a temple also known as Takechiji 高市寺; later he moved to Nara.

49 Hizōki shishō, in Nichizō, 117. The numbering of the arguments is by Gōhō; parts between quotation marks are translations by the author, other parts are paraphrases.
} 
shorai mokuroku 御請来目録 (Catalogue of Imported Items) ${ }^{50}$ from which we may conclude that Zenmui brought it and Kūkai was not the first to import it. ${ }^{51}$ If the text brought by Zenmui would have been in Sanskrit, Kūkai would definitely have brought a copy in Chinese with him; it is after all a crucial text for his form of Buddhism, and it would have been in his list.

The Kumedera ryūki says that he deposited seven scrolls. The Tobu yōmoku 都部 要目 (List of [Darani for the] Heads of the [Mandara] Divisions) ${ }^{52}$ says that the short version from the Tang is in seven kan; therefore this must have been the translation.

Gōō does not find the story in the Fusō ryakki plausible; "Zenmui finished the translation in Kaiyuan $13(725)^{53}$ and died in Kaiyuan 23 (735). However, the mysterious changes of the great saint and his virtue are unimaginable." Is Gōhō being ironic?

Gōhō concludes his lists of arguments with two references, one to a text related to Kashima Daimyōjin 鹿 島大明神 and one to the famous Taima mandala 当 麻曼茶羅 which shows influences of the Chinese text. These needn't concern us here.

This list of arguments appears time and again in the commentaries. Gōō himself ends this part of his explanation by saying that there must be no doubt that this is the text which encouraged Kükai to go and study in China and, further, that this fact is the traditional kuketsu, the oral definition of the reason why the Sanskrit title is placed here opening the text. Actual kuketsu on the sentence are either found in the text itself or in the Great Commentary.

\section{Doctrinal Framework}

Yūsen 雄仟 (dates unknown), writing in 1668, takes the discussion away from the mere historical orientation and supposes an overall doctrinal framework as an underlying structure in the Hizōki, pointing out that while the text opens with the Dainichikyō, it concludes with the Ekō darani 回向陀羅尼 from the Shugo(kokkai-

\footnotetext{
50 KDZ I: 69-104. This is Kūkai's list of materials he brought with him from China; it was a list for official use.

51 Actually, Dōji 道慈 (?-744) would be more obvious since he studied under Zenmui and also brought texts on the Gumonjiho to Japan.

52 Tobu darani moku 都部陀羅尼目, T 18, 903.

53 This is a mistake in the text, made by Gōhōo or a copyist.
}

shudarani)-kyō 守護國界陀羅尼経. ${ }^{54}$ The Dainichikyō is placed at the head of the text because it represents the world of compassion in the Womb-store (Taizō-bu) and concerns the virtues attached to the causes leading to realization (intoku 因徳). The above-mentioned Shugo-kyo, on the other hand, reasons from the world of the pinnacle of wisdom (Kongōchō-bu), and expresses the virtues attached to the domain of result (katoku 果 德) in the Kongōkai. He writes: "You should understand that in a process of development from the cause to the result, Dainichikyo is placed at the beginning of the work and Shugokyo last." ${ }^{55}$

\section{Conclusion}

In the discussion above I have tried to make clear that a study of the transmission and education system particular to certain lineages may inform us about the present-day situation of Shingonshū lineages, the way they frame their identity, and the concepts and tools that are important to them. I have taken up the kōden sessions because they offer an integrated form of ritual and doctrinal explanations. The actual explanations delve into the past for an authorization of their tenets and esoteric definitions, searching for confirmation and corroboration in the works of Kükai and later exegetes, but the actual synthesis of the past and present is made on the spot.

The tasks of the teachers in such cases are not only a historical reconstruction and perpetuation of the past. The major point seems to be to explain what is important for the profession of today's priests. For the identity of the lineage itself, they devise and construct a consistent system of lore analysed in depth following both age-old conventions and an inherent logic derived from the basic perspective on reality and the state of man in it and as part of it. For the education of the priests, reference is made to the accepted explanations concerning the biography of the founder, the necessities for the ritual performance, the basic view that the universe appears as a combination of various mandara which can be used as maps showing the distribution of meanings, and as many of the dogmas and tenets that the ajari chooses to present. It is outside my scope here

54 Hizōki shiyōshō, ZSZ XVI: 371-72. The sutra is T 19, 997.

55 lbid., 372. 
to compare the qualities of individual teachers; for the Shingon priest they are all Dainichi Nyorai anyway.

One example, in this case from the Hizoki kōden, is taken to illustrate that exegetes as well as the ajari distribute their explanations within an overall scheme of inherited meanings and redefined concepts which has grown over the centuries, a scheme that sets boundaries to the discussion. The first thing that is clear from the example of the title of the Dainichikyō is that a mere translation does no justice to the way this line is treated by a particular lineage nor does it reveal the interpretation in contemporary Japan. It follows that to rely on a certain edition of a text, for instance taken from the Kōbo Daishi zenshū, is no guarantee for insight into other lineages than the one of the editors of this collection. ${ }^{56}$

Secondly, when I compare the various explanations, the accents placed by different teachers on a varying number of inherited "truths" appear to be important for the lineages to frame their identity and distinguish them from other lineages. As I showed, the first line or chapter of the Hizōki spawned a number of discussions among the exegetes, and I could easily extend this discussion and show particularities in the following chapters of this text or discuss other texts where such particularities of interpretation show the emphasis of the ritual linage. As a matter of fact, the chapter following our example here is about the integrated mandara (ryōbu mandara 両部曼茶羅). Some readers conclude from the sparse information in the text that this concerns a genzu mandara 現図曼茶羅, a mandara displaying the appearances of its inhabitants, others that this ryōbu mandara is lifted from the collections of the original Kongōchōgyō-cycle.

From a reading of the commentaries, independently or in the setting of the koden, it becomes clear that besides conventional argumentation other methods and tools are employed to confront the problems; in fact, the exegetes have their own strategies to solve questions. In this discussion of the first "Chapter", I have shown some of the tools they can wield. The quasi-historical

56 In Roger Goepper, "Mandala Speculation in Shingon Buddhism Based on the Hizōki and its Commentaries," in Embodying Wisdom, Art, Text and Interpretation in the History of Esoteric Buddhism, Robert Linrothe and Henrik H. Sorensen, eds. (Copenhagen: The Seminar for Buddhist Studies, 2001), 37-56, a study of the mandala view presented in the Hizōki, I miss this realization that Mt. Kōya does not equal Shingonshū. approaches, the lore, and the textual evidence that can be brought to the discussion, do not differ from commentators from non-esoteric schools. However, their ploy of using the constructed esoteric world of meanings differs from other networks of meanings as we can find, for example, in the Taimitsu tradition. A study of a selected system of one specific lineage will reveal additional meanings again in abundance, all presumed to be included in Kūkai's insights in "reality," but will also yield meanings that set the lineage apart from others.

In my example I showed a number of ramifications and included subjects which may appear to digress from the central argument. However, I find that in order to show the actual working of this kind of education it is not my task to weed out certain parts of the contents. I had to make choices, but the topics presented here are the actual content considered important for the teachers of the kōden.

What the inquiry into the kōden also shows, I think, is that a study of the debates and commentaries may bring to light how the various schools deal with their heritage, hold on to their identities as separate traditions, and, moreover, what they find important in their own architecture of lore. The results of such studies augment our understanding of these ritual schools over mere translation. Moreover, even though we cannot acquire the esoteric information in its entirety, we can deduce from the discussions in the sources available to us what the real foundation is of each of the views and attitudes that are often just heaped together as Shingonshū. In this case as well the contemporary debates presented in the education system may be the best starting point to understand the role and identity the professional priests see for themselves in present-day Japan.

I must add in conclusion that I was fortunate to receive instruction from highly respected ajari. In the case of the Hizōki kōden I received kōka kanjō from Ueda Reijō and attended his sessions over a three-year period from 2002-04. I am well aware that this path and these opportunities are not open to all. The denjuroku and the commentaries, however, are easily obtainable nowadays, and these texts provide excellent explanations in themselves for the study of the ritual networks that carry Shingonshū in their titles or their heritage.

In the denju and kōden transmissions we find the basic formulation of the present temple activities, not in the doctrinal works by Kükai; of importance is how interesting these may be in themselves. Gōhō's Shishō 
has an okugaki 奥書, postscript, which says that the denjuroku contains the "esoteric definitions that have been passed on in the lineage" (sōshōhiketsu 相承秘 決) which he transmitted to Kenbō 賢宝(1333-98). This instruction is then called "a profound secret which is found on the bottom of a box." The manuscript concludes with: "don't show this to others!" 57 To truly understand the world of the Shingon priest it is best to consider the education he has received and investigate the explanations these texts prefer to keep from us.

\section{Chronological List of Most Important Commentaries}

1222 Hizōshō 秘蔵抄 (1 kan), often called Zōchū Ya$k i n-s h \bar{o}$ 蔵中冶金抄. The instructor was Henchiin Joken 成賢 and the notes are by Shinken 深賢 (?-1261), the founder of the Daigo Jizōin 醍醐地蔵院. The transmission took place in Jōō 貞応 1 (1222) in Ōjōin Rengenotani of Mt. Kōya 高野山往生院蓮花谷. ZSZ vol. XV. The text is mentioned by Gōhō.

Hizōkishō 秘蔵記鈔//抄 (1 kan), also called Hisōden$s h \bar{o}$ 非相伝抄. Transmission by Jōhen 静遍, recorded by Shōchi-in Dōhan 道範 (1178-1252). ZSZ vol. XV: 35-58.

1283 Hizōshō 秘蔵抄 (7 kan). The title inside is Hizōki shimonsho 秘蔵記私聞書; the author is unknown. The transmission took place in Kōan 弘安 6 (1283) from the $24^{\text {th }}$ day of the third month and was recorded in Kamakura Sazame no tani 鎌倉佐々目谷. SZ IX: 41- 133 .

Hizōki shiki 秘蔵記私記 ( 4 or 5 kan). The title inside is Hizōki shi nikki 禾草言私日記, the author is unknown. Oyama mentions that "one tradition" attributes the text to Raiyu.

Before 1309 Hizōkikanmon 秘蔵記勘文 (3kan), composed or copied by Shinnichi 信日, who died Engyō 延 慶 2 (1309). ZSZ vol. XVI. The okugaki says: Karyaku 嘉暦 3/4/28 (1325/4/28) copied by Kongōbusshi Junjin 純臣.
1309 Hizōki kikigaki 秘蔵記聞書 (6 kan), also called Hizōki himonshō 秘蔵記秘聞鈔 but this text is in 3 kan. The lecturer was Jishō Shōnin Gahō 自性上人我宝 and the transmission was recorded by Raihō 頼宝. The last day of the transmission was on the $29^{\text {th }}$ day of the eighth month of Engyō 延慶 2 (1309). ZSZ vol. XV.

1314-42 Hizōki zōkanshō 秘蔵記蔵勘(肝)抄 (5 kan). As above, the lecturer was Gahō, but now the instruction was noted down by Shōmudōin Dōga 聖無動院道 我. The transmission took place in Shōwa 正和 3 (1314), five years after the sessions recorded by Raihō, but the text was only completed in Ryakuō 暦応 5 (1342). ZSZ vol. XV. The sessions were held in a place called Sendō gosho 仙洞御所.

1352 Hizōki shishō 秘蔵記私鈔 (10 kan). This is the influential commentary composed by Gōhō 果宝 (1306-62) in Kannō 観応 3 (1352). Nihon Daizōkyō Shingonshū jissō shōsho 日本大蔵経真言宗事相章疏.

1371 Hizōki gusō 秘蔵記愚草 (5 kan). Title inside Hizōki kikigaki 秘蔵記聞書. The transmission of Kenbō 賢宝 recorded by Shōjun 清俊 in Ōan 応安 4 (1371). ZSZ vol. XV.

1413 Hizōki zōdanshō 秘蔵記蔵談抄 (2 kan). Titles inside are Hizōki denjushō 秘蔵記伝授抄 as well as Zōmonshō 雑聞鈔. This is the transmission from Yūkai 宥快 (1345-1416) recorded by Kaizen 快全 in Ōei 応 永 2 (1413). ZSZ vol. XVI. A later copy from Mt. Kōya's Shinnōin 親王院 is discussed in Gyōei bunko 堯榮文 庫 3 .

1635 Hizōki hōshōgōki 秘蔵記宝性合記 (10 kan). Recorded by Kenkai 建海 in Kan'ei 寛永 12 (1635). ZSZ vol. XVI.

1668 Hizōki shiyōshō 秘蔵記旨要抄 (5 kan) by Yōchiin Yūsen 桜池院雄任 from Kanbun 寛文 8 (1668). ZSZ vol. XVI.

1842 Hizōki shūyōki 秘蔵記拾要記 (9 kan) by the Chizan prelate Ryūyū 智山能化隆瑜 from Tenpo 天保 3 (1842). SZ vol. IX.

57 Hizōki shishō, in Nichizō, 351. 


\section{Bibliography}

\section{ABBREVIATIONS}

DNBZ = Dainihon bukkyō zensho 大日本仏教全書. 150 vols. Edited by Bussho Kankōkai 仏書刊行会. Tokyo: Daihōrinkaku, 2007.

$\mathrm{KDZ}=$ Kōbō Daishi zenshū 弘法大師全集. 8 vols. Edited by Hase Hōshu 長谷宝秀. Osaka: Mikkyō Bunka Kenkyūjo 1965-68.

Nichizō = Nihon daizōkyō 日本大蔵経. 51 vols. Edited by Nakano Tatsue 中野達慧 et al. Tokyo: Nihon Daizōkyō Hensankai, 1914-19.

SZ = Shingonshū zensho 真言宗全書. 44 vols. Edited by Shingonshū Zensho Kankōkai 畺言宗全書刊行會. Wakayama: Kōyasan Daigaku Shuppanbu, 2004.

$\mathrm{T}=$ Taishō shinshū Daizōkyō 大正新修大蔵経. 100 vols. Edited by Takakusu Junjirō 高楠順次郎 et al. Tokyo: Taishō Issaikyō Kankōkai, 1924-32.

ZSZ = Zoku Shingonshu zensho 続真言宗全書. 42 vols. Wakayama: Kōyasan Daigaku Shuppanbu, 2008.

\section{KŌDENROKU}

Nasu Seiryū 那須正隆. “Hizōki kōden 秘蔵記講伝.” In vol. 7 of Nasu Seiryū chosakushū 那須正隆著作集, 1-262. Kyoto: Hōzōkan, 1997.

Oda Jishu 小田慈舟. “Hizōki kōden kiyō 秘蔵記講伝紀 要.” In vol. 2 of Oda Jishu kōdenroku 小田慈舟講伝録, 197-401. Osaka: Tōhō shuppan, 1990.

Ōyama Kōjun 大山公淳記. “Hizōki kōden 秘蔵記講伝.” In vol. 2 of Ōyama Kōjun sentoku kakigiki shūsei: Kōdenmon 大山公淳先徳聞書集成: 講伝門, 173-234. Osaka: Tōhō shuppan, 1995.

Ueda Reijō 上田霊城. Hizōki kōden 秘蔵記講伝. Kyoto: Dōmeisha, 2002. . Rishukyō kōroku 理趣経講録. Kyoto: Dōmeisha, 2002.

Bohner, Herman. "Kobo Daishi." Monumenta Nipponica 6, no. 1 (1943): 266-313.

Demiéville, Paul, Hubert Durt, and Anna Seidel, eds. Répertoire du canon bouddhique Sino-Japonais: Edition de Taishō. Hōbōgirin, appendix volume. Paris: L’Académie des inscriptions et belles-lettres, Institut de France, 1978.

Goepper, Roger. "Maṇdala Speculation in Shingon Buddhism Based on the Hizōki and Its Commentaries." In Embodying Wisdom, Art, Text and Interpretation in the History of Esoteric Buddhism. Edited by Robert Linrothe and Henrik H. Sorensen, 37-56. Copenhagen: The Seminar for Buddhist Studies, 2001.

Great Commentary, Daisho 大疏, on the Dainichikyō 大日 経. Daibirushanajōbutsukyōsho 大毘盧遮那成佛經疏, T 39. 1796.

Hodge, Stephan, trans. The Mahā-vairocana-abhisambodhi Tantra: With Buddhaguhya's Commentary. London: RoutledgeCurzon, 2003.

Kojiruien Kankōkai 古事類苑刊行会, ed. Kojiruien 古事類 苑. Kyoto: Yoshikawa Kōbunkan, 1927-30.

Mikkyō Jiten Hensankai 密教辭典編纂会, ed. Mikkyō daijiten 密教大辞典, Kyoto: Hōzōkan 1991.

Miyata, Taisen. Handbook on the Four Stages of Prayoga Chüin Branch of Shingon Tradition. Wakayama: Kōyasan Shingonshū Kyōgakubu, 1988.

Mukai Ryūken 向井隆健. “Hizōki seiritsu kō 秘蔵記成 立考.” Mikkyōgaku kenkyū 密教学研究 15 (December 1983): 53-67.

"Fukūyaku Shōmugekyō to Hizōki to no kankei ni tsuite 不空訳「摂無礙経」と「秘蔵記」との関係に ついて.”Buzan kyōgaku taikai kiyō 豊山教学大会紀要 9 (1981): 13-24.

Nakagawa Zenkyō 中川善教. “Hizōki ni tsuite no josetsu 秘蔵記についての序説.” Mikkyōgaku kenkyū 1 (March 1969): 41-68.

“Hizoki no futatsu no mondai 秘蔵記の二つの問 題.” ZSZ kaihō 会報 (1984): 1-4.

Ōzawa Shōkan 大沢聖寛. "Hizōki no shahon ni tsuite 秘 蔵記の写本について.” Buzan gakuhō 豊山学報 26-27 (March 1982): 49-59.

“Hizōki no ikkōsatsu 秘蔵記の一考察.” Taishō

Daigaku Daigakuin kenkyū ronshū 大正大学大学院研究 論集 1 (1977): 95-108.

. "Hizōki no senjutsu nendai ni tsuite 秘蔵記の選

述年代について.” Mikkyōgaku kenkyū 24 (March 1992): 47-61.

Payne, Richard K. The Tantric Ritual of Japan: Feeding the Gods: The Shingon Fire Ritual. New Delhi: International Academy of Indian Culture \& Aditya Prakashan, 1991.

Sharf, Robert H. "Thinking through Shingon Ritual," Journal of the International Association of Buddhist Studies 26, no. 1 (2003): 51-96.

Takagi Shingen 高木訷元. Kūkai: Shōgai to sono shūhen 空 海:生涯とその周辺. Tokyo: Yoshikawa Kōbunkan, 1997.

Ueyama Shunpei 上山春平. Kūkai. Tokyo: Asahi Shuppansha, $1992[2002(3)]$. 